セッション 3-B-8

\title{
新しい非侵襲的動脈硬化度測定法としての 動脈壁血管開口速度測定の意義
}

\author{
新 啓一郎 ${ }^{1)}$ 和田 光弘 ${ }^{2)}$ 美並真由美 ${ }^{1)}$ \\ 庄司きぬ子1) 須賀 正江 $^{1)}$ 荻野 淑郎 ${ }^{1)}$
}

\section{目 的}

血圧測定時にカフ圧がわずかでも収縮期血圧以下に なると, カフ圧下の血管の中枢側が開口し血液が末梢 側まで運ばれる。この動脈壁の変形によりもたらされ る血管開口伝播の速度 $(\mathrm{OV})$ は血管壁の粘弾性を反映 するものと考元られる。OV は再現性もよく, 同一被験 者では心拍数や血圧の変化の影響を受けず, 加龄に伴 い減少する。本研究では OV と年齢との関係を多数の 健常者より求め, さらに動脈硬化の危険因子である糖 尿病 $(\mathrm{DM})$, 高脂血症 (HL), 高血圧 $(\mathrm{HT})$ および 冠動脈疾患 (CAD) 患者で OV を測定し, 動脈硬化度 の指標としての有用性を検討した。

\section{対象と方法}

健常者 765 例において OV と年齢との関係を調べ た。健診受診者のうち 30 歳から 60 歳代の正常者 113 例（男 61 例，女 52 例）で年龄・性別の OV を調べ, さらに $40 \sim 60$ 歳の軽症の $\mathrm{DM}(n=10), \mathrm{HL}(n=16)$, $\mathrm{HT}(n=16)$ を有するものの OV を年齢を一致させた 健常者 $(\mathrm{N}, n=20)$ と比較した。なお， DM は HbA $1 \mathrm{c}$ が $6.5 \%$ から 7.5\%のもの, HL は血清総コレステロー ル（TC）が 220〜 $270 \mathrm{mg} / \mathrm{dl}$ あるいは中性脂肪（TG） が 200〜 400 mg/dl のもの, HT は境界域高血圧のもの
を対象とした。また，主として 40 歳代の冠動脈造影検 査にて $75 \%$ 以上の狭窄を有する入院患者 (CAD) 14 例 でOVを調べた。OV は BIMS-V (マクター社)によ り，上腕動脈にて測定した。

\section{結 果}

健常者 756 例では OV は加跲に伴い減少した（ $r=$ $-0.61, p<0.01)$ 。健診受診者の正常者の OV も男女 とも加齢に伴い減少した $(r=-0.56, p<0.05) 。 \mathrm{OV}$ 平均値は女性で 40 歳代までは男性より高值を示した が, 50 歳代以降は男性と同様に低下した。DM, HL で は同年齢の正常者 $(\mathrm{N})$ に比べ OV は低值を示したが, $\mathrm{HT}$ では差はなかった（N $0.65 \pm 0.02[\mathrm{SE}] \mathrm{m} / \mathrm{sec} v$

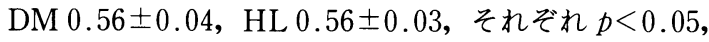
HT $0.63 \pm 0.04)$ 。CAD 患者でも同年齢の健常者に比 べ低値を示した $(0.51 \pm 0.03 \mathrm{~m} / \mathrm{sec}$ vs $0.68 \pm 0.04, p$ $<0.05)$ 。

\section{考察および結論}

OV は加齢に伴い減少した。また, 動脈硬化性疾患で 低值を示し, 冠動脈狭窄患者ではさらに低值を示した。 OV 測定は簡便であり, 再現性も良好であるので健診 における動脈硬化度のスクリーニング検査とし有用だ と思われる。

Opening Propagation Velocity of the Collapsed Brachial Artery as a New Noninvasive Means of Arteriosclerosis Evaluation

1）藤間病院 総合健診システム

2) マクター(株) 